\title{
Tezy prawne z zakresu prawa karnego wydawane przez polskie (nieniemieckie) sądy apelacyjne w Generalnym Gubernatorstwie (1940-1943)*
}

\section{WSTĘP}

Prawo karne w niemieckim ustroju nazistowskim pełniło rolę instrumentalną wobec polityki państwa. Służyło do skazywania na karę, pod pozorem legalności, przeciwników reżimu. Objawiało się to m.in. tworzeniem różnego rodzaju sądów mających charakter „,specjalny”, „,doraźny”2 czy „ludowy”, jak również wydawa-

* Publikacja została przygotowana w ramach projektu badawczego „Charakter prawny i rola tez prawnych uchwalanych przez polskie (nieniemieckie) sądy apelacyjne w Generalnym Gubernatorstwie w okresie II wojny światowej", finansowanego ze środków Narodowego Centrum Nauki na podstawie umowy nr UMO-2017/27/N/HS5/00812.

${ }^{1}$ O sądach specjalnych: K. Graczyk, Sądy specjalne III Rzeszy jako „sądy doraźne frontu wewnętrznego” (1933-1945), „Miscellanea Historico-Iuridica” 2019, t. 18, z. 2, s. 165-201.

2 Sądy doraźne wchodziły w skład „sądownictwa policyjnego”, praktycznie nie istniały różnice między działalnością policyjną a sądową tych organów. W literaturze powszechnie uznaje się, że nie powinny być traktowane jako sądy w ścisłym tego słowa znaczeniu. Od 1942 r. Heinrich Himmler negocjował z Otto Thierackiem, ministrem sprawiedliwości Rzeszy, przekazanie „sądownictwu policyjnemu" całości sądownictwa karnego w sprawach przeciwko obywatelom radzieckim, Polakom, Sinti i Roma oraz Żydom na polskich ziemiach wcielonych do Rzeszy i najprawdopodobniej w GG. Zdaniem Himmlera każde przestępstwo popełnione przez osobę „narodowo obcą” zagrażało niemieckiemu porządkowi narodowemu. Ostatecznie w wyniku oporu gauleiterów oraz wysokich przedstawicieli sądownictwa nie doszło do przekazania tych kompetencji organom policyjnym. M. Becker, Sadownictwo niemieckie i jego rola w polityce okupacyjnej na ziemiach polskich wcielonych do Rzeszy 1939-1945, Warszawa 2020, s. 181-183; P. Longerich, Himmler. Buchalter śmierci, Warszawa 2014, s. 775-778, 800-801; K.M. Pospieszalski, Odpowiedzialność naczelnych zwierzchników administracji terenowej za zbrodnie wojenne w okupowanej Polsce, „Przegląd Zachodni” 1962, t. 2, nr 3, s. 9-10; A. Wrzyszcz, Okupacyjne sadownictwo niemieckie w Generalnym Gubernatorstwie 1939-1945. Organizacja i funkcjonowanie, Lublin 2008, s. 65-67.

3 Więcej na temat Trybunału Ludowego (Volksgerichtshof): R.D. Rachlin, Roland Freisler nad the Volksgerichtshof: The Court as an Instrument of Terror [w:] A.E. Steinweis, R.D. Rachlin (red.), 
niem licznych aktów prawnych, bezpośrednio lub pośrednio skierowanych przeciwko „wrogom”, przede wszystkim ,narodowo obcym”, co tworzyło system oparty w dużym stopniu na pozakodeksowych normach prawnokarnych ${ }^{4}$. W szerszym kontekście prawo karne pełniło więc rolę represyjną, eliminacyjną, a nawet eksterminacyjną Co oczywiste, z uwagi na istnienie zdefiniowanych „wrogów” nie każdy człowiek był w równym stopniu objęty ochroną prawa. Wynika to z cechy totalitarnego prawa, jaką jest programowa nierówność, i złamania w ten sposób zasady powszechności prawa ${ }^{6}$. W jakiejś formie jednak „racjonalne”, ,apolityczne” normy prawa karnego w państwie totalitarnym nadal obowiązywały. Zazwyczaj były to normy zastane przez reżim w momencie przejęcie władzy. Oczywiście w sądowym procesie stosowania prawa mogły one także zostać użyte do realizacji celów politycznych. Przede wszystkim jednak miały spełniać funkcje swoiste dla prawa karnego ${ }^{7}$.

Podobnie wyglądała sytuacja w obszarze prawa karnego w Generalnym Gubernatorstwie [dalej: GG] ${ }^{8}$. Sądownictwo oraz system prawa odzwierciedlały totalitarny, nazistowski model prawa karnego. Jednocześnie pozostawione zostały

The Law in Nazi Germany. Ideology, Opportunism, and The Perversion of Justice, New York Oxford 2013, s. 63-89; S. Schädler, ,Justizkrise” und „Justizreform” im Nationalsozialismus: das Reichsjustizministerium unter Reichsjustizminister Thierack (1942-1945), Tübingen 2009, s. 9098. Franz Neumann, jeden z najważniejszych komentatorów nazistowskiego ustroju państwowego, widział w funkcjonowaniu specjalnych sądów przykład podporządkowania prawa celom polityki nazistowskiej, jego silnej polityzacji i utraty przez prawo w państwie nazistowskim racjonalnego charakteru. F. Neumann, Behemot. Narodowy socjalizm. Ustrój i funkcjonowanie 1933-1944, Warszawa 2016, s. 524-527.

${ }^{4}$ A. Fermus-Bobowiec, M. Szewczak-Daniel, Prawo karne $w$ stużbie ideologii i jako narzędzie eksterminacji na przykładzie prawa karnego dla Polaków i Żydów na terenach wcielonych do III Rzeszy [w:] W. Kozyra, I. Lasek-Surowiec, A.M. Zaręba (red.), Druga wojna światowa. Wybrane zagadnienia konfliktu międzynarodowego, Chełm 2015, s. 195-204; D. Majer, „Non-Germans” under the Third Reich. The Nazi Judicial and Administrative System in Germany and Occupied Eastern Europe, with Special Regard to Occupied Poland, 1939-1945, Lubbock, Te 2013, s. 411-469.

${ }^{5}$ Więcej na temat funkcji prawa: W. Uruszczak, Perwersyjne funkcje niemieckiego ,prawa" w Generalnym Gubernatorstwie 1939-1945, „Z Dziejów Prawa” 2019, t. 12 (20), s. 681-708.

${ }^{6}$ Ibidem.

7 O funkcjach prawa karnego m.in.: J. Makarewicz, Wstep do filozofii prawa karnego w oparciu o podstawy historyczno-rozwojowe, Lublin 2009, s. 51-147. Literacki obraz takiej dychotomii prawa karnego przedstawił J. Littell w głośnej powieści Łaskawe. Główny bohater, Maximilian Aue, oficer SD, jest zbrodniarzem wojennym, uczestnikiem i świadkiem Holocaustu oraz m.in. policyjnych egzekucji wykonywanych na podstawie „nazistowskiego”, „wypaczonego” prawa karnego. Jest funkcjonariuszem państwa prerogatywnego, działającego poza prawem, ewentualnie na gruncie fikcyjnej legalności. Jednocześnie jest ścigany przez funkcjonariuszy Kriminalpolizei (KriPo) za kryminalne zbrodnie, których się dopuścił. J. Littell, Łaskawe, Kraków 2008.

${ }^{8}$ Jak argumentowały władze niemieckie: „Jest to [stosowanie niemieckiego prawa karnego H.M.] [...] konieczne, gdyż sędzia karny przy zwalczaniu panującego w Polsce już przed wojną bandytyzmu - i to w stopniu dla niemieckich stosunków wprost niewyobrażalnym - potrzebuje koniecznie bronić niemieckiego prawa karnego z jego skutecznymi przepisami względem używających gwałtu oraz zawodowych zbrodniarzy"; za: AAN, Ministerstwo Informacji i Dokumentacji 
„resztki państwa prawa”, państwo normatywne, organy działające na podstawie i w graniach prawa9 .

Artykuł ten jest poświęcony jednej z instytucji prawnych, która mieściła się w zmiennych granicach państwa normatywnego. Jego celem jest analiza wydanych przez sądy apelacyjne tez prawnych z zakresu prawa karnego. Były to najważniejsze wypowiedzi jurydyczne sądów polskich (nieniemieckich) ${ }^{10} \mathrm{w}$ GG. Przedstawiona zostanie dokładna statystyka wydanych tez, a tym samym poszerzona wiedza na temat stosowania prawa karnego przez sądy polskie (nieniemieckie), przede wszystkim w odniesieniu do rodzajów spraw, jakie były rozpatrywane przez sądownictwo polskie (nieniemieckie) w GG, oraz związanych z nimi problemów prawnych. W szerszym kontekście analiza ta pozwoli odpowiedzieć na pytanie o działalność sądów polskich (nieniemieckich) w Generalnym Gubernatorstwie. Czy sądy te były wykorzystywane do prowadzenia polityki nazistowskiej w GG w sprawach karnych?

\section{WŁAŚCIWOŚĆ RZECZOWA SĄDÓW W SPRAWACH KARNYCH W GENERALNYM GUBERNATORSTWIE}

W Generalnym Gubernatorstwie w systemie sądownictwa funkcjonowały sądy, które miały charakter wyłącznie prawnokarny. Były to sądy specjalne i policyjne

Rządu RP [emigracyjnego] w Londynie, sygn. 105, k. 261. Opracowanie K. Willego „Wymiar sprawiedliwości w Generalnym Gubernatorstwie".

${ }^{9}$ Odnosi się to do teorii Ernsta Fraenkla „podwójnego państwa”. E. Fraenkel, The Dual State. A Contribution to the Theory of Dictatorship, Oxford 2017. Najbardziej aktualna interpretacja tej teorii: E.J. Meierhenrich, The Remnants of the Rechtstaat. An Etnography of Nazi Law, Oxford 2018, passim.

${ }^{10}$ Autor konsekwentnie używa w całym artykule podwójnej nazwy „sądownictwo polskie (nieniemieckie)". Określenie „sądownictwo polskie” pochodzi z języka prawnego Generalnego Gubernatorstwa, po raz pierwszy pojęcie „sądownictwo nieniemieckie” pojawiło się w rozporządzeniu w sprawie odbudowy wymiaru sprawiedliwości w okręgu Galizien (Galicja) z 1 sierpnia 1941 r. (Dziennik Rozporządzeń Generalnego Gubernatorstwa, nr 68, s. 445) i odnosiło się do sądów w dystrykcie Galicja - pojawiło się więc w momencie zwiększenia podmiotowości politycznej w GG ludności ukraińskiej. Oba określenia: „sądownictwo polskie” i „sądownictwo nieniemieckie" pochodzą zatem z języka prawnego GG. po utworzeniu dystryktu Galicja zasadą miało stać się stosowanie nazwy ,sądownictwo nieniemieckie” także na określenie sądów funkcjonujących w czterech pierwotnych dystryktach GG. Z przebadanego materiału archiwalnego wynika jednak, że zarówno władze niemieckie, jak i przedstawiciele polskich (nieniemieckich) sądów używali w wewnętrznych pismach prawie do końca okupacji raz określenia sądy, sądownictwo „polskie”, sędziowie „polscy”, a raz „nieniemieckie”, ,nieniemieccy”, przy czym od mniej więcej połowy $1942 \mathrm{r}$. określenie „nieniemieckie” stało się częściej stosowaną formą. Stosowanie podwójnej nazwy ma na celu podkreślenie nadzoru sprawowanego przez władze niemieckie nad tym pionem sądownictwa. Taka nazwa nie sugeruje, że w GG działała administracja „polska”. Pozwala też wyraźnie oddzielić pion oficjalnego sądownictwa powszechnego od sądownictwa Polskiego Państwa Podziemnego. 
sądy doraźne ${ }^{11}$. Ich głównym celem, zwłaszcza w odniesieniu do „sądownictwa doraźnego", było uproszczenie postępowania karnego i pod pozorem legalizmu prowadzenie terroru sądowego, dostosowanego do celów polityki w $\mathrm{GG}^{12}$. Jednocześnie obok tych sądów działało sądownictwo powszechne, składające się z dwóch pionów: niemieckiego i polskiego (nieniemieckiego) ${ }^{13}$. Brakowało wyraźnego rozgraniczenia właściwości rzeczowej pomiędzy sądami niemieckimi i polskimi (nieniemieckimi) ${ }^{14}$. W zakresie prawa karnego obszar właściwości sądownictwa niemieckiego był szeroki ${ }^{15}$. Podlegały mu wszystkie osoby w GG, niezależnie od narodowości. Ustawodawstwo niemieckie GG w aktach prawnych z zakresu prawa karnego przewidywało właściwość sądownictwa niemieckiego, dopiero od 1942 r. możliwe było formalne rozpatrywanie przez sądy polskie (nieniemieckie) czynów zagrożonych karą w rozporządzeniach generalnego gubernatora. Przy czym możliwe to było tylko wtedy, gdy nie dochodziło w tych przypadkach do działania na szkodę niemiecką ${ }^{16}$.

Każda sprawa o charakterze karnym, niezależnie od narodowości oskarżonego, pokrzywdzonego i innych uczestników oraz podstawy prawnej, była badana przez

${ }_{11}$ Pełny opis niemieckich organów sądowych w GG: A. Wrzyszcz, Okupacyjne sądownictwo niemieckie..., s. 59-130.

${ }^{12} \mathrm{Na}$ temat policyjnych sądów doraźnych: A. Wrzyszcz, Kompetencje „,sądownicze” policji niemieckiej w Polsce w czasie II wojny światowej [w:] S. Grodziski, A. Dziadzio (red.), Regnare, gubernare, administrare. $Z$ dziejów administracji, sądownictwa i nauki prawa. Prace dedykowane profesorowi Jerzemu Malcowi z okazji 40-lecia pracy naukowej, Kraków 2012, s. 127-137.

${ }^{13} \mathrm{Na}$ temat sądownictwa polskiego (nieniemieckiego): H. Mielnik, Sądownictwo polskie (nieniemieckie) w dystrykcie lubelskim Generalnego Gubernatorstwa w latach 1939-1944, Lublin 2020; A. Szulczyński, Sadownictwo polskie w Generalnym Gubernatorstwie 1939-1945, Warszawa 2020.

${ }^{14}$ H. Mielnik, Sadownictwo polskie (nieniemieckie)..., s. 102-105.

${ }^{15}$ Zgodnie z przepisami prawa GG nie-Niemcy podlegali niemieckim sądom, jeśli popełnili następujące czyny:

1) skierowane przeciw bezpieczeństwu i autorytetowi Rzeszy Niemieckiej i narodu niemieckiego, przeciwko jego interesom oraz przeciw życiu, zdrowiu, czci i majątkowi osób posiadających niemiecką przynależność państwową lub narodowości niemieckiej,

2) zagrożone karą w rozporządzeniach generalnego gubernatora lub urzędów przezeń upoważnionych,

3) popełnione w budynku, pomieszczeniu lub zakładzie służącym celom władzy niemieckiej,

4) popełnione w służbie zarządu niemieckiego lub w związku z tą służbą.

Rozszerzenie właściwości sądownictwa niemieckiego dotyczyło także współsprawców, pomocników, popleczników i paserów. W postępowaniach toczących się wobec kilku osób, jeżeli chociaż jedna z nich podlegała sądownictwu niemieckiemu, to wszystkie podlegały sądownictwu niemieckiemu. Jeżeli przeciwko temu samemu podejrzanemu toczyło się kilka postępowań, sądownictwo niemieckie było właściwe dla wszystkich spraw, gdy przynajmniej jeden czyn należał do jego jurysdykcji. Za: Rozporządzenie o sądownictwie niemieckim w Generalnym Gubernatorstwie z dnia 19 lutego 1940 r. (Dziennik Rozporządzeń Generalnego Gubernatora dla okupowanych polskich obszarów, dalej: Dz.RGGOP, cz. I, nr 13, s. 57-63), § 7 ust. 2-3.

${ }^{16}$ A. Wrzyszcz, Okupacyjne sadownictwo..., s. 168-169. 
niemiecką prokuraturę (początkowo stosowano pojęcie ,władza oskarżenia”) i mogła zostać przeniesiona z sądownictwa polskiego (nieniemieckiego) do sądownictwa niemieckiego. Nie było wyraźnych kryteriów wskazujących na właściwość sądów niemieckich, a zmiana właściwości zależała wyłącznie od decyzji niemieckiej prokuratury ${ }^{17}$. Sędziowie polscy (nieniemieccy) byli zobowiązani do przekazania sprawy do niemieckiej prokuratury na każdym jej etapie, jeżeli powstały jakiekolwiek wątpliwości mogące sugerować zmianę właściwości ${ }^{18}$.

Kryteria oceny właściwości w sprawach karnych zmieniały się w czasie okupacji niemieckiej. Na początku okupacji prokuratura niemiecka przekazywała sądom niemieckim wszystkie sprawy dotyczące poważnych przestępstw, jak np. zabójstwa, niezależnie od okoliczności sprawy, nawet jeżeli oskarżony czy pokrzywdzony nie byli Niemcami. W późniejszych latach przekazywane były już tylko te sprawy, w których ujawniono naruszenie szeroko pojętych interesów niemieckich ${ }^{19}$. Tak kwestię rozdziału właściwości w sprawach karnych pomiędzy dwoma pionami sądownictwa scharakteryzował i uzasadnił Kurt Wille, kierownik Głównego Wydziału Sprawiedliwości w Rządzie Generalnego Gubernatorstwa:

W dziedzinie prawa karnego granice niemieckiego sądownictwa są wytknięte jeszcze dalej. Nie tylko Niemcy podlegają wyłącznie niemieckiemu sądownictwu karnemu, lecz każda osoba odnośnie tych przestępstw, które w jakikolwiek sposób skierowują się przeciwko bezpieczeństwu, poważaniu i interesom niemieckiego Państwa lub władzy, albo przeciwko obywatelom niemieckim lub przynależnym do narodu niemieckiego, albo odnośnie tych przestępstw, które zostały zagrożone karą rozporządzeniami Generalnego Gubernatora. [...] Przed sądem specjalnym można ponadto [...] oskarżać o każde przestępstwo, jeżeli osądzenie przez tenże sąd jest wskazane z uwagi na ciężki charakter albo wyjątkową podłość czynu, albo na wywołane nim wśród ogółu poruszenie. Przez tego rodzaju uregulowanie miano zapewnić, by zwalczanie ciężkiej przestępczości, na której wytępieniu administracji niemieckiej $\mathrm{w}$ interesie bezpieczeństwa kraju $\mathrm{w}$ wysokim stopniu zależy, leżało w rękach wypróbowanych niemieckich sędziów, którzy z niemieckiego poczucia porządku wkraczają energicznie do walki z przestępstwem ${ }^{20}$.

17 Przepis $\S 1$ ust. 2 rozporządzenia o sądownictwie polskim z 19 lutego 1940 r. (Dz.RGGOP, cz. I, nr 13, s. 64-68) brzmiał: „W sprawach karnych rozpoznać może sąd polski tylko wtedy, gdy sprawa została przekazana przez niemiecką władzę oskarżenia polskim władzom”.

${ }^{18}$ Władze niemieckie przykładały dużą wagę do kwestii podziału właściwości. Instruowano sędziów, że pierwszą czynnością, jaka ma być dokonana po wzięciu do ręki akt sprawy karnej, miało być potwierdzenie, że sprawa została przekazana przez niemiecką prokuraturę. H. Mielnik, Sąownictwo polskie (nieniemieckie)..., s. 325-329.

19 A. Wrzyszcz, Okupacyjne sądownictwo..., s. 168-169. Potwierdza to analiza rodzajów spraw karnych rozpatrywanych w sądach polskich (nieniemieckich) przeprowadzona w odniesieniu do dystryktu lubelskiego: H. Mielnik, Sądownictwo polskie (nieniemieckie)..., s. 409-417.

${ }^{20}$ AAN, Ministerstwo Informacji i Dokumentacji Rządu RP [emigracyjnego] w Londynie, sygn. 105, k. 258-259. Opracowanie K. Willego „Wymiar sprawiedliwości w Generalnym Gubernatorstwie". 
Podział właściwości rzeczowej w zakresie spraw karnych ukazuje faktyczną rolę sądownictwa polskiego (nieniemieckiego), które działało wyłącznie w zakresie dopuszczonym przez ramy stworzone przez władze niemieckie. Podział właściwości był płynny, najprawdopodobniej determinowany wytycznymi kierowanymi przez centralne i dystryktowe władze niemieckie. Na pewno jednak zakres przedmiotowy kognicji sądów polskich (nieniemieckich) w obszarze prawa karnego został wyraźnie ograniczony w porównaniu do okresu przedwojennego. Znamiennym faktem jest to, że polscy adwokaci reprezentujący osoby, którym groziła odpowiedzialność karna w sprawach, w których doszło do jakiegokolwiek naruszenia niemieckich interesów, starali się przede wszystkim - sposobami legalnymi, a nawet nielegalnymi - doprowadzić do pozostawienia sprawy we właściwości sądów polskich (nieniemieckich) ${ }^{21}$. Słusznie bowiem zakładali, że sytuacja procesowa oskarżonego będzie znacznie lepsza w sądownictwie polskim (nieniemieckim).

\section{TEZY PRAWNE SĄDÓW APELACYJNYCH W GENERALNYM GUBERNATORSTWIE}

Rozporządzeniem o sądownictwie polskim z 19 lutego 1940 r. władze niemieckie uregulowały ustrój sądów polskich (nieniemieckich) w GG, oparty w głównej mierze na przedwojennych polskich rozwiązaniach ${ }^{22}$. Najważniejszą wprowadzoną zmianą była likwidacja Sądu Najwyższego ${ }^{23}$. Jednocześnie akty prawne regulujące ustrój Generalnego Gubernatorstwa sprawiły, że system prawa stał się skompliko-

${ }^{21}$ K. Pędowski, Jeszcze o „Patronacie”, „Palestra” 1972, t. 16, nr 9, s. 48-49.

22 Dalsze obowiązywanie polskiego prawa zostało określone w dwóch aktach prawnych tworzących podstawy ustrojowe Generalnego Gubernatorstwa: 1) dekret Führera i Kanclerza Rzeszy Niemieckiej o administracji okupowanych polskich obszarów z dnia 12 października 1939 r. (A. Weh, Prawo Generalnego Gubernatorstwa w układzie rzeczowym z objaśnieniami i szczegółowym skorowidzem, Kraków 1941, A100, § 4), który zawierał postanowienie: „prawo dotychczas obowiązujące pozostaje dalej w mocy, o ile nie sprzeciwia się objęciu administracji przez Rzeszę Niemiecką"; 2) rozporządzenie o odbudowie administracji okupowanych polskich obszarów z 26 października 1939 r. (Dz.RGGOP, nr 1, s. 3, § 8), które przewidywało, że „,dotychczasowe prawo polskie zachowuje moc swoją, o ile nie jest w sprzeczności z przejęciem Administracji przez Rzeszę Niemiecką i wykonaniem wojskowych praw niemieckich". Oba przepisy wyraźnie podkreślały prymat prawa niemieckiego nad polskim. Przepis $\S 4$ rozporządzenia o sądownictwie polskim z 19 lutego $1940 \mathrm{r}$. (Dz.RGGOP, cz. I, nr 13, s. 64-68) brzmiał: „Dla wykonania polskiego sądownictwa obowiązują polskie ustawy i rozporządzenia, o ile Generalny Gubernator nie postanawia inaczej”.

${ }^{23}$ Przepis $\S 5$ ust. 2 rozporządzenia o sądownictwie polskim z 19 lutego 1940 r. (Dz.RGGOP, cz. I, nr 13, s. 64-68) brzmiał: „Sąd Najwyższy nie podejmuje chwilowo swojej czynności”. Faktycznie jednak powołana została Komisja Likwidacyjna Sądu Najwyższego, której zadaniem było płynne usunięcie z systemu sądownictwa sądu najwyższej instancji, a Sąd Najwyższy nie podjął czynności przez cały okres okupacji. 
wany i nieuporządkowany, wręcz chaotyczny ${ }^{24}$. Jednym z pierwszych problemów merytorycznych, z jakimi musiały mierzyć się sądy polskie (nieniemieckie) po ich uruchomieniu w pierwszym kwartale 1940 r., była kwestia interpretacji prawa w procesie jego stosowania. Likwidacja Sądu Najwyższego pociągnęła za sobą usunięcie z ustroju sądownictwa wszystkich instytucji procesowych (zasady prawne; orzecznictwo Sądu Najwyższego) służących do ujednolicania orzecznictwa sądowego, których głównym zadaniem było rozstrzyganie wątpliwości interpretacyjnych ${ }^{25}$.

Pod koniec 1940 r. Kurt Wille zdecydował o przekazaniu polskim (nieniemieckim) sądom apelacyjnym kompetencji do utworzenia biur orzecznictwa, które zajmowałby się analizą orzecznictwa, rozstrzyganiem problemów prawnych i przez to ujednolicaniem orzecznictwa ${ }^{26}$. Była to dość zaskakująca decyzja, zważywszy, że w nazistowskim ustroju sądownictwa na polskich ziemiach wcielonych do Rzeszy Niemieckiej kwestia ujednolicania orzecznictwa była pozostawiona czynnikom politycznym. Omawianie orzecznictwa w sprawach karnych, a tak naprawdę jego pośrednie sterowanie, odbywało się poprzez wytyczne przedstawiane przez prezydentów wyższych sądów krajowych na konferencjach z prezydentami sądów krajowych oraz przewodniczącymi sądów specjalnych ${ }^{27}$. Na ziemiach polskich wcielonych do Rzeszy Niemieckiej w sądownictwie powszechnym sterowanie orzecznictwem było jeszcze bardziej widoczne w zakresie spraw cywilnych. Gauleiterzy (namiestnicy Rzeszy) uzyskali prawo do wydawania sądom zaleceń w sprawach o znaczeniu ,politycznym”. Procedura ta polegała na przekazywaniu odpowiednich dyrektyw prezydentom sądów krajowych, którzy odpowiadali za ujednolicenie $w$ ich duchu orzecznictwa sądowego. Miały one przede wszystkim służyć nakierowaniu sędziów na orzekanie w duchu nazistowskiego prawa. Od przejęcia władzy w Rzeszy Niemieckiej przez narodowych socjalistów tworzono różne mechanizmy mające za zadanie politycyzację orzecznictwa. Przedstawiciele Ministerstwa Sprawiedliwości prowadzili konferencje z prezydentami wyższych sądów krajowych oraz prokuratorami generalnymi. W czasopismach prawniczych pojawiały się artykuły omawiające konkretne wyroki sądowe. Do sędziów przesyłane były także listy z interpretacją poszczególnych wyroków. W literaturze brakuje

${ }^{24}$ Więcej na temat systemu prawa GG: H. Mielnik, Sądownictwo polskie (nieniemieckie)..., s. $127-151$.

${ }^{25}$ Więcej na temat działalności orzeczniczej Sądu Najwyższego w II RP: D. Malec, Sąd Najwyższy w latach 1917-1939 [w:] A. Korobowicz (red.), Sąd Najwyższy Rzeczypospolitej Polskiej. Historia i współczesność, Warszawa 2007, s. 121-191; R.A. Stefański, Instytucja pytań prawnych do Sądu Najwyższego w sprawach karnych, Kraków 2001, s. 25-54.

${ }^{26}$ Archiwum Państwowe w Radomiu [dalej: APR], Sąd Apelacyjny w Radomiu 1939-1945, sygn. 4, k. 1, Zarządzenie kierownika Sądu Apelacyjnego w Radomiu z 25 lipca 1941 r. w sprawie tez prawnych.

${ }_{27}$ M. Becker, Sadownictwo niemieckie i jego rola ..., s. 82, 92, 142, 146, 205-210. 
jednoznacznej oceny skuteczności działań sterujących orzecznictwem sądownictwa w III Rzeszy. Najprawdopodobniej działania te miały charakter wyłącznie psychologiczny, a ich nieprzestrzeganie nie pociągało za sobą bezpośrednich skutków zawodowych dla sędziów ${ }^{28}$.

Procedura wydawania tez prawnych była opracowywana w samych polskich (nieniemieckich) sądach, kierownicy dystryktowych wydziałów sprawiedliwości akceptowali przedstawione im projekty ${ }^{29}$. W czterech pierwotnych dystryktach GG przyjęto rozwiązania nawiązujące do przedwojennych przepisów regulujących kompetencje Sądu Najwyższego do ujednolicania orzecznictwa. Regulacje obowiązujące w poszczególnych dystryktach różniły się między sobą, w niektórych sądach apelacyjnych procedura wydawania tez prawnych przypominała procedurę uchwalania przedwojennych zasad prawnych, w innych zaś opracowywano tezy wyłącznie na gruncie prawomocnych orzeczeń. Nie w każdym z sądów apelacyjnych dopuszczono możliwość zadawania sądowi pytań prawnych ${ }^{30}$. Jednocześnie, pomimo postulatu skierowanego do władz niemieckich przez sędziego Kazimierza Rudnickiego, kierownika Sądu Apelacyjnego w Warszawie, nie wyrażono zgody na powołanie jednego biura orzecznictwa dla całego $\mathrm{GG}^{31}$. Wynikało to przede wszystkim z decentralizacji sądownictwa polskiego (nieniemieckiego), które podlegało władzom poszczególnych dystryktów. Brak organów centralnych, zwłaszcza Sądu Najwyższego, ale także postulowanego centralnego biura orzecznictwa, miał osłabiać pozycję całego sądownictwa polskiego (nieniemieckiego) ${ }^{32}$.

Pozostawienie w gestii polskich (nieniemieckich) sądów apelacyjnych stworzenia ram prawnych do wydawania tez prawnych może wskazywać na kilka kwestii. Przede wszystkim tezy prawne nie miały służyć wywieraniu wpływu na orzecznictwo sądowe i przez to realizację celów polityki nazistowskiej. Znajdowały się one poza zainteresowaniem władz niemieckich. W dystrykcie krakowskim dystryktowy wydział sprawiedliwości miał być informowany tylko o tych tezach,

${ }^{28}$ Ibidem, s. 209-210; L. Gruchmann, Justiz im Dritten Reich 1933-1940. Anpassung und Unterwerfung in der Ära Gürtner, München 2001, s. 1141-1143.

${ }^{29}$ Archiwum Narodowe w Krakowie [dalej: ANK], Sąd Apelacyjny w Krakowie 1919-1950, sygn. 31, brak paginacji, pismo kierownika Sądu Apelacyjnego w Warszawie do kierownika Sądu Apelacyjnego w Krakowie z 20 grudnia 1940 r. w sprawie biura orzecznictwa.

${ }^{30} \mathrm{~W}$ każdym z sądów apelacyjnych odmiennie wyglądała procedura wydawania tez prawnych. Ich charakterystyka na podstawie wyników badań dotyczących charakteru prawnego tez prawnych sądów apelacyjnych z okresu GG zostanie przedstawiona w kolejnych publikacjach autora.

31 APR, Sąd Apelacyjny w Radomiu 1939-1945, sygn. 4, k. 8, wniosek kierownika Sądu Apelacyjnego w Warszawie z 20 grudnia 1940 roku w sprawie utworzenia biura orzecznictwa w Sądzie Apelacyjnym w Warszawie.

32 AAN, Ministerstwo Informacji i Dokumentacji Rządu RP [emigracyjnego] w Londynie, sygn. 105, k. 262. Opracowanie K. Willego „Wymiar sprawiedliwości w Generalnym Gubernatorstwie"; H. Mielnik, Sadownictwo polskie (nieniemieckie)..., s. 62-67. 
w których doszło do interpretacji prawa wydanego w $\mathrm{GG}^{33}$. Tezy prawne miały przede wszystkim służyć rozwijaniu wątpliwości interpretacyjnych przez sądy ostatniej instancji w GG. Władze GG nie miały odpowiedniego, wykształconego i posiadającego dostateczną wiedzę na temat polskiego prawa aparatu prawniczo-urzędniczego ${ }^{34}$. Z czysto praktycznych względów trudne było więc dla władz niemieckich w GG wyjaśnianie wszystkich wątpliwości prawnych pojawiających się w praktyce orzeczniczej sądów polskich (nieniemieckich). Sędzia K. Rudnicki tak opisywał i oceniał instytucję tez prawnych:

W teraźniejszych warunkach działalność Biura Orzecznictwa, zwłaszcza skoro nie ma być centralnego biura orzecznictwa, obejmującego wszystkie okręgi apelacyjne, lecz przewidziane są tylko biura orzecznictwa przy poszczególnych sądach apelacyjnych [faktycznie wyodrębnione strukturalnie biuro orzecznictwa powstało wyłącznie przy Sądzie Apelacyjnym w Warszawie, w pozostałych sądach funkcje zbierania, opracowywania orzecznictwa oraz prowadzenia zbioru tez pełniły sekretariaty prezydialne, ewentualnie sekretariaty wydziałów - H.M.], musi być sprowadzona do znacznie skromniejszych rozmiarów; uważam jednak, że przy należytej organizacji biur orzecznictwa przy sądach apelacyjnych nawet i obecnie, w ramach zakreślonych przez Wydział Sprawiedliwości przy Urzędzie Generalnego Gubernatora, mogą to być nader pożyteczne instytucje, których zadaniem będzie zachowanie myśli prawniczej obecnie zawartej w orzeczeniach sądów wyrokujących w II-ej, a zarazem obecnie ostatniej instancji, następnie ułatwienie pracy sędziom, mającym do rozstrzygnięcia zawiłe zagadnienia prawne, przez informowanie ich o poglądzie na daną kwestię dotychczasowego orzecznictwa, wreszcie przyczynienie się choćby w pewnym tylko stopniu do ujednostajnienia judykatury sądowej. Że biura orzecznictwa przy sądach apelacyjnych mają mieć poważne zadania do spełnienia, to wynika i z pisma Gubernatorstwa z d. 4 grudnia r.b. [1940 - H.M.], które do obowiązków biura orzecznictwa przenosi nie samo tylko sporządzanie tez prawnych z orzeczeń, lecz również badanie rozstrzygnięć sądów pod względem ich zasadniczego znaczenia dla ogólnej praktyki sądowej ${ }^{35}$.

Warto podkreślić, że tezy prawne miały charakter wyłącznie opiniodawczy i informacyjny, były fachowymi opiniami sądu ostatniej instancji. Nie wiązały one sądów niższych instancji, z wyjątkiem tych sytuacji, gdy teza prawna została wydana na tle konkretnej sprawy ${ }^{36}$.

33 ANK, Sąd Apelacyjny w Krakowie 1919-1950, sygn. 31, brak paginacji, zarządzenie kierownika Sądu Apelacyjnego w Krakowie z 21 stycznia 1941 r. w sprawie zbioru orzeczeń.

${ }^{34}$ H. Mielnik, Sąownictwo polskie (nieniemieckie)..., s. 127-138.

35 APR, Sąd Apelacyjny w Radomiu 1939-1945, sygn. 4, k. 10, pismo kierownika Sądu Apelacyjnego w Warszawie w sprawie biura orzecznictwa.

36 Archiwum Państwowe w Lublinie [dalej: APL], Sąd Okręgowy w Lublinie 1939-1944, sygn. 1/63, k. 74-75, zarządzenie kierownika Sądu Apelacyjnego w Lublinie z 14 marca 1941 r. w sprawie uchwalania tez prawnych. 


\section{TEZY PRAWNE SĄDÓW APELACYJNYCH W GENERALNYM GUBERNATORSTWIE Z ZAKRESU PRAWA KARNEGO}

Procedura wydawania tez prawnych została uregulowana w każdym z dystryktów do końca pierwszego kwartału 1941 r. Jednocześnie przyjęto rozwiązanie zakładające możliwość wydania tezy prawnej na podstawie orzeczeń sądów apelacyjnych z $1940 \mathrm{r} \cdot{ }^{37}$ Ostatnie tezy prawne z zakresu prawa karnego pochodziły najprawdopodobniej z $1943 \mathrm{r}$. Tezy prawnocywilne były wydawane jeszcze w pierwszym kwartale 1944 r., ale tylko w Sądzie Apelacyjnym w Warszawie ${ }^{38}$. Wynikało to najprawdopodobniej z faktu działalności przy warszawskim sądzie biura orzecznictwa z pracownikami zajmującymi się wyłącznie analizą orzecznictwa $^{39}$. W pozostałych sądach apelacyjnych, tak jak w całym sądownictwie polskim (nieniemieckim), mniej więcej od drugiej połowy 1943 r. wyraźnie maleje ruch spraw. Sądownictwo powoli przechodzi w stan swoistego „wegetowania”, władze niemieckie w niewielkim stopniu wydają nowe okólniki i zarządzenia, kierowane do polskich (nieniemieckich) sądów. Wzmaga się dążenie do uproszczenie postępowań i szeroko pojętej oszczędności w każdym obszarze działalności sądów. Wpływ na to miał wzrost terroru wprowadzonego w polityce okupanta (co skutkowało przede wszystkim reakcją organów policyjnych, a nie sądowych, na czyny zabronione) oraz zbliżający się od wschodu front $t^{40}$. $\mathrm{Z}$ tych powodów tezy prawne $\mathrm{z}$ zakresu prawa karnego polskich (nieniemieckich) sądów apelacyjnych, które zostaną opracowane, pochodzily z okresu czterech lat: od 1940 do $1943 \mathrm{r}$.

W wyniku przeprowadzonej kwerendy archiwalnej odnaleziono 49 tez prawnokarnych. Niestety, pomimo stale prowadzonych badań nie udało się dotrzeć do źródeł dotyczących problematyki tez prawnych Sądu Apelacyjnego we Lwowie. $\mathrm{Z}$ dużym prawdopodobieństwem można założyć, że także we lwowskim sądzie była możliwość wydawania tez prawnych. $Z$ pozostałych czterech pierwotnych

37 ANK, Sąd Apelacyjny w Krakowie 1919-1950, sygn. 31, brak paginacji, zarządzenie kierownika Sądu Apelacyjnego w Krakowie z 21 stycznia 1941 r. w sprawie zbioru orzeczeń; Archiwum Państwowe w Warszawie [dalej: APW], Sąd Okręgowy w Warszawie 1917-1944, sygn. 9, brak paginacji, pismo kierownika Sądu Apelacyjnego w Warszawie z 2 marca 1941 r. w sprawie utworzenia Biura Orzecznictwa w Sądzie Apelacyjnym w Warszawie.

38 APL, Sąd Apelacyjny w Lublinie 1918-1939, sygn. 13/8, brak paginacji. Zbiory tez i opinii opracowanych przez Biuro Orzecznictwa przy Sądzie Apelacyjnym w Warszawie z pierwszego kwartału $1944 \mathrm{r}$.

${ }^{39}$ APW, Sąd Okręgowy w Warszawie 1917-1944, sygn. 9, brak paginacji, pismo kierownika Sądu Apelacyjnego w Warszawie z 2 marca 1941 r. w sprawie utworzenia Biura Orzecznictwa w Sądzie Apelacyjnym w Warszawie.

${ }^{40}$ H. Mielnik, Sadownictwo polskie (nieniemieckie)..., s. 420-427. 
dystryktów na uwagę zwraca przykład nowo utworzonego w GG Sądu Apelacyjnego w Radomiu, w którym nie wydano ani jednej tezy prawnej dotyczącej prawa karnego ${ }^{41}$. Analizie można poddać więc tezy pochodzące z trzech sądów apelacyjnych: lubelskiego, krakowskiego i warszawskiego.

W porównaniu do tez cywilnoprawnych liczba tez z zakresu prawa karnego była prawdopodobnie mniejsza. Przy czym realną różnicę można zaobserwować w sądzie radomskim i warszawskim, gdzie znacznie więcej wydano tez z zakresu prawa cywilnego. Istotny jest przypadek warszawskiego sądu apelacyjnego, z działalności którego udało się odnaleźć wyłącznie 14 tez prawnokarnych i aż 612 tez prawnocywilnych ${ }^{42}$. Zaburzenie proporcji jest tak duże, że być może od 1942 r. mogły być publikowane oddzielne działy karne i cywilne zbioru tez i opinii. Przy czym nie udało się znaleźć i przebadać, pomimo przeprowadzonej kwerendy, zeszytów karnych. Wszędzie bowiem w gorszym stanie zachowane są akta wydziałów karnych sądów z okresu okupacji niemieckiej, zarówno organizacyjne, jak i akta postępowań sądowych ${ }^{43}$. W apelacji lubelskiej wydawano prawie tyle samo tez z obu obszarów prawa - cywilnych cztery, karnych pięć ch $^{4}$ W Sądzie Apelacyjnym w Krakowie wydawano znacznie więcej tez karnych (30) niż cywilnych $(12)^{45}$. Trudno jest wyjaśnić liczbę tez poszczególnych sądów i znaleźć przyczyny przedstawionych dysproporcji. W odróżnieniu od prawa cywilnego prawo karne zostało w II RP ujednolicone i te same akty prawne obowiązywały we wszystkich apelacjach sądowych GG.

Najwięcej tez prawnych z obszaru prawa karnego wydanych zostało przez Sąd Apelacyjny w Krakowie. Czternaście tez pochodziło z warszawskiego Sądu Apelacyjnego, a tylko pięć z lubelskiego. Różnice między poszczególnymi sądami wynikają przede wszystkim z przyjętych rozwiązań proceduralnych, prowadzących do sformułowania/wydania tezy. W krakowskim Sądzie Apelacyjnym tezy prawne stanowiły wyciąg z prawomocnych orzeczeń tego sądu (chociaż istniała także możliwość sformułowania tezy na gruncie orzeczeń sądów okręgowych, podjętych w drugiej instancji; w apelacji krakowskiej nie było jednak ani jednego

${ }^{41}$ Tezy prawne z Sądu Apelacyjnego w Radomiu znajdują się w: APR, Sąd Apelacyjny w Radomiu 1939-1945, sygn. 5.

${ }^{42}$ APL, Sąd Apelacyjny w Lublinie 1918-1939, sygn. 13/5; 13/8, brak paginacji. Zbiory tez i opinii opracowanych przez Biuro Orzecznictwa przy Sądzie Apelacyjnym w Warszawie.

${ }^{43}$ Jako przykład można podać, że w maju 1944 r. sądy z dystryktu lubelskiego dostały rozkaz przygotowania do wywiezienia akt sądowych. Część akt została wywieziona albo zniszczona na miejscu. AAN, Ministerstwo Sprawiedliwości w Warszawie 285, sygn. 6995, k. 17.

${ }^{44}$ Opracowanie tez z dystryktu lubelskiego w: H. Mielnik, Sąownictwo polskie (nieniemieckie)..., s. 401-409.

45 ANK, Sąd Apelacyjny w Krakowie 1919-1950, sygn. 31; ANK, Sąd Okręgowy w Krakowie 1939-1945, sygn. 3020; APL, Sąd Apelacyjny w Lublinie 1918-1939, sygn. 13/5; APR, Sąd Apelacyjny w Radomiu 1939-1945, sygn. 5. 
Tabela 1 . Wykaz tez prawnych z zakresu prawa karnego

\begin{tabular}{|c|c|c|c|c|c|c|}
\hline Tezy prawne & 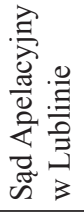 & 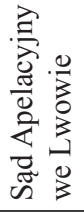 & 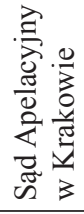 & 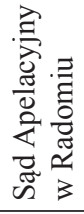 & 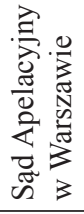 & Łącznie \\
\hline Tezy materialnoprawne & 2 & \multirow{3}{*}{ b.d. } & 11 & 0 & 11 & 24 \\
\hline Tezy procesowe & 3 & & 19 & 0 & 3 & 25 \\
\hline Łącznie & 5 & & 30 & 0 & 14 & 49 \\
\hline
\end{tabular}

Źródło: opracowanie własne na podstawie ANK, Sąd Apelacyjny w Krakowie 1919-1950, sygn. 31; ANK, Sąd Okręgowy w Krakowie 1939-1945, sygn. 3020; APL, Sąd Apelacyjny w Lublinie 1918-1939, sygn. 13/5; APR, Sąd Apelacyjny w Radomiu 1939-1945, sygn. 5.

takiego przypadku ${ }^{46}$. W apelacji warszawskiej także stanowiły one wyciąg z prawomocnych orzeczeń Sądu Apelacyjnego oraz Sądów Okręgowych w Warszawie i Siedlcach, przy czym za ich opracowanie, jak już zostało wspomniane, odpowiadało odrębne strukturalnie biuro orzecznictwa. W Sądzie Apelacyjnym w Lublinie tezy prawne były formułowane w odrębnej od postępowania sądowego procedurze, przez powiększone składy sądzące, stąd też niewielka liczba oficjalnie wydanych tez w apelacji lubelskiej ${ }^{47}$. Rzadko bowiem dostrzegano dostateczną doniosłość problemu prawnego, która stanowiłaby przesłankę do uchwalenia tezy w powiększonym składzie sędziowskim.

$\mathrm{Na}$ liczbę tez wpływało także informowanie się sądów apelacyjnych o wydanych tezach, były one bowiem rozsyłane pomiędzy dystryktami, czasami za pośrednictwem władz niemieckich, czasami bezpośrednio pomiędzy kierownikami sądów apelacyjnych ${ }^{48}$. Największą i najlepiej zorganizowaną działalność „wydawniczą” prowadził warszawski Sąd Apelacyjny, który publikował kwartalnie specjalnie opracowywane, opatrzone komentarzem „Zbiory tez i opinii opracowanych przez Biuro Orzecznictwa przy Sądzie Apelacyjnym w Warszawie"49. Pozostałe sądy

${ }^{46}$ ANK, Sąd Apelacyjny w Krakowie 1919-1950, sygn. 31, brak paginacji, pismo kierownika Sądu Apelacyjnego w Krakowie z 31 stycznia 1941 r. do kierowników sądów okręgowych i przewodniczących wydziałów zamiejscowych w sprawie przeysłania orzeczeń do Sądu Apelacyjnego w Krakowie.

${ }^{47}$ APL, Sąd Okręgowy w Lublinie 1939-1944, sygn. 1/63, k. 74-75, zarządzenie kierownika Sądu Apelacyjnego w Lublinie z 14 marca 1941 r. w sprawie uchwalania tez prawnych.

48 ANK, Sąd Apelacyjny w Krakowie 1919-1950, sygn. 31, brak paginacji, pismo kierownika Wydziału Sprawiedliwości w Urzędzie Szefa Dystryktu Krakowskiego z 18 czerwca 1941 r. w sprawie przesyłania tez prawnych do innych dystryktów.

49 APL, Sąd Apelacyjny w Lublinie 1918-1939, sygn. 13/5, brak paginacji, pismo kierownika Wydziału Sprawiedliwości w Urzędzie Gubernatora Dystryktu Warszawskiego z 30 czerwca 1943 r. 
przesyłały skopiowane na powielaczu tezy prawne, zawierające zwykle uzasadnienie do orzeczenia albo przynajmniej jego część.

Mniej więcej tyle samo tez dotyczyło kwestii materialnoprawnych (24), co procesowych (25). Z zakresu prawa procesowego najwięcej tez (7) poświęconych było problematyce związanej z postępowaniem apelacyjnym. Pozostałe tezy dotyczyły różnych rozproszonych kwestii z zakresu postępowania karnego, takich jak: opinie biegłych, odroczenie i przerwa wykonania kary, wznowienie postępowania czy koszty sądowe. Dwie tezy prawne procesowe oparte zostały na przepisach rozporządzenia o sądownictwie polskim z 19 lutego $1940 \mathrm{r}$. Jedna z nich dotyczyła $\S 5$ rozporządzenia, a druga $\S 11$ rozporządzenia. Obie miały charakter wyłącznie merytoryczny i techniczny. Dla przykładu można przytoczyć tezę Sądu Apelacyjnego w Krakowie opartą na postanowieniu z dnia 15 marca 1941 r., sygn. I KZ 9/41:

I. Brzmienie przepisu § 11 rozporządzenia Generalnego Gubernatora o sądownictwie polskim w Generalnym Gubernatorstwie z dnia 19 lutego 1940 roku: „Wydane w drugiej instancji orzeczenie sądu okręgowego są ostateczne" stwierdza w sposób nieulegający wątpliwości, że przepis ten uznaje za ostateczne tylko te orzeczenia sądu okręgowego, które wydane zostały w drugiej instancji, a zatem tylko te orzeczenia, które zapadły wskutek rozpoznania danego środka odwoławczego i są jego załatwieniem, gdyż tylko w tym wypadku orzeczenie odnośne zostaje $\mathrm{w}$ drugiej instancji ${ }^{50}$.

Oprócz tych dwóch tez, opartych na przepisach rozporządzenia o sądownictwie polskim z 19 lutego 1940 r., jedna teza prawna dotyczyła artykułu z przepisów o kosztach sądowych z 1932 r. ${ }^{51}$ Wszystkie pozostałe odnosiły się do przepisów kodeksu postępowania karnego z $1928 \mathrm{r}^{52}$ (w przypadku tez procesowych) oraz kodeksu karnego z $1932 \mathrm{r}^{53}$ (w przypadku tez prawnomaterialnych).

Analiza tez prawnych z zakresu prawa karnego materialnego wskazuje, że najwięcej tez dotyczyło przepisów regulujących przestępstwa przeciwko mieniu (10), przestępstwa przeciwko dokumentom (5) i przestępstwa przeciwko porządkowi publicznemu (3), na kolejnych miejscach znajdują się przestępstwa przeciwko życiu i zdrowiu (2) oraz przestępstwa urzędnicze (2). Rodzaje tez prawnych z zakresu prawa karnego materialnego odpowiadają najczęściej rozpatrywanym przez

do kierowników sądów apelacyjnych w Krakowie, Lublinie, Lwowie i Radomiu w sprawie zbioru orzeczeń Sądu Apelacyjnego w Warszawie.

${ }^{50}$ ANK, Sąd Apelacyjny w Krakowie 1919-1950, sygn. 31, brak paginacji, teza I KZ 9/41.

${ }^{51}$ Rozporządzenie Prezydenta Rzeczypospolitej z dnia 27 października 1932 r. - Przepisy o kosztach sądowych (Dz. U. nr 93, poz. 805).

${ }^{52}$ Obwieszczenie Ministra Sprawiedliwości z dnia 16 stycznia 1939 r. o ogłoszeniu jednolitego tekstu kodeksu postępowania karnego (Dz. U. 1939, nr 8, poz. 44).

${ }_{53}$ Rozporządzenie Prezydenta Rzeczypospolitej z dnia 11 lipca 1932 r. - Kodeks karny (Dz. U. nr 60, poz. 571). 
Tabela 2. Rodzaje przestępstw, których dotyczyły tezy prawne sądów apelacyjnych

\begin{tabular}{|l|c|c|}
\hline \multicolumn{1}{|c|}{ Rozdział kodeksu karnego z $1932 \mathrm{r}}$. & Artykuły & Liczba tez \\
\hline $\begin{array}{l}\text { Przestępstwa przeciwko władzom i urzędom } \\
\text { Przestępstwa przeciwko porządkowi publicz- } \\
\text { nemu }\end{array}$ & art. 129 & 1 \\
Fałszowanie pieniędzy, papierów wartościo- & art. $160(\times 2)$, art. 163 & 3 \\
wych, znaków urzędowych i narzędzi mier- & art. 175 & 1 \\
niczych & & \\
Przestępstwa przeciwko dokumentom & art. 187 (× 3), art. 190, art. 191 & 5 \\
Przestępstwa przeciwko życiu i zdrowiu & art. 236, art. 240 & 2 \\
Zniewagi & art. 256 & 1 \\
Przestępstwa przeciwko mieniu & art. 257 (×2), art. 262 (×2), art. & 10 \\
Przestępstwa urzędnicze & $264(\times 4)$, art. 269, art. 271 & 2 \\
\hline
\end{tabular}

Źródło: opracowanie własne na podstawie ANK, Sąd Apelacyjny w Krakowie 1919-1950, sygn. 31; ANK, Sąd Okręgowy w Krakowie 1939-1945, sygn. 3020; APL, Sąd Apelacyjny w Lublinie 1918-1939, sygn. 13/5; APR, Sąd Apelacyjny w Radomiu 1939-1945, sygn. 5.

sądy polskie (nieniemieckie) w dystrykcie lubelskim sprawom karnym ${ }^{54}$. Można założyć, że także w pozostałych dystryktach były to najczęściej rozpatrywane rodzaje spraw karnych. Najczęściej rozpatrywanymi przestępstwami przez sądy polskie (nieniemieckie) były bowiem kradzieże, przywłaszczenia mienia, związane z tymi przestępstwami paserstwa, fałszerstwa dokumentów oraz lekkie i średnie uszkodzenia ciała.

Część tez prawnych poruszała też problematykę przepisów części ogólnej kodeksu karnego z 1932 r. W czterech tezach Sądu Apelacyjnego w Krakowie głównym przedmiotem interpretacji była obrona konieczna (art. 21 k.k. z 1932 r.). Pozostałe tezy dotyczyły m.in. instytucji usiłowania (art. 23), zapobieżenia przestępstwu przez pomocnika lub podżegacza (art. 30) czy zatarcia skazania (art. 90).

Najważniejsze zagadnienie, jakie pojawia się w odniesieniu do tez prawnych z zakresu prawa karnego, dotyczy wpływu na nie warunków okupacyjnych i polityki prowadzonej przez władze niemieckie. $Z$ jednej strony chodzi o ewentualne interpretacje prawa służące realizacji polityki nazistowskiej, z drugiej - o ujawnienie problemów prawnych związanych z realiami życia pod okupacją w GG. Analiza treści tez prawnych wydanych przez polskie (nieniemieckie) sądy apelacyjne wskazuje, że ani pierwsza, ani druga kwestia się w nich nie pojawiała. Tezy prawne miały charakter wyłącznie merytoryczny i profesjonalny, większość tez stanowiła interpretacje przepisów zgodne z przedwojennymi komentarzami i orzecznictwem Sądu Najwyższego. Nie zawierały one przy tym interpretacji trudnych proble-

${ }^{54}$ H. Mielnik, Sądownictwo polskie (nieniemieckie)..., s. 409-417. 
mów prawnych. Jako przykład można podać treść dwóch tez Sądu Apelacyjnego w Warszawie: „Wyraz »bójka« oznacza starcie się więcej, jak dwóch osób” (teza oparta na wyroku SA w Warszawie z 5 lutego 1941 r., sygn. KA 178/40) czy „Zabór mienia pozostawionego przez właściciela w określonym miejscu stanowi kradzież, a nie przywłaszczenie" (wyrok SA w Warszawie z 9 stycznia 1941 r., sygn. I KA $144 / 40)^{55}$. Trudno jest także, poza przedmiotem tez, który pokrywa się z najczęściej rozpatrywanymi sprawami karnymi, odnaleźć w ich treści nawiązanie do realiów okupacyjnych. Jedyny przykład, w którym przywołano okoliczności związane z warunkami wojennymi, stanowi teza Sądu Apelacyjnego w Warszawie, oparta na wyroku z 24 stycznia 1941 r. (sygn. I KA 122/40), odnosząca się do dostarczenia drewna na budowę schronów publicznych:

Właściciel (państwo czy też miasto, czy wreszcie osoba prywatna), dostarczając swego drzewa do budowy schronów publicznych, tym samym z prawa swego własności jeszcze nie rezygnuje, lecz drzewa tylko użycza na czas ogólnego niebezpieczeństwa ${ }^{56}$.

Całkowicie należy wykluczyć wykorzystywanie tez prawnych do narzucania sądom interpretacji prawa $\mathrm{w}$ duchu nazistowskim lub do realizacji celów prowadzonej polityki. Tylko w jednej z tez można doszukać się nawiązania do zaleceń stawianych polskim (nieniemieckim) sądom przez władze niemieckie. Jak już wspomniano, podział właściwości między sądami polskimi (nieniemieckimi) a niemieckimi był płynny. Jednym z kryteriów przekazywania spraw do sądownictwa niemieckiego było ujawnienie w sprawie warunków recydywy, przestępczości zawodowej lub nałogowej. Takie sprawy miały być na każdym etapie postępowania przekazywane prokuraturze niemieckiej, która decydowała o właściwości sprawy ${ }^{57}$. Do tej problematyki nawiązywała teza Sądu Apelacyjnego w Krakowie (I KA 357/41), zawierająca definicję przestępcy zawodowego (art. 60 § 2 k.k.). Kodeks karny z 1932 r. nie wprowadził definicji legalnej przestępcy zawodowego, ponieważ ,są to pojęcia [zawodowość oraz nawyknienie - H.M.] tego rodzaju, iż nie poddają się traktowaniu schematycznemu, a muszą być pozostawione ocenie sędziowskiej w poszczególnym wypadku" 58 . Przyjęta przez krakowski sąd definicja brzmiała:

${ }^{55}$ APL, Sąd Apelacyjny w Lublinie 1918-1939, sygn. 13/5; 13/8, brak paginacji. Zbiory tez i opinii opracowanych przez Biuro Orzecznictwa przy Sądzie Apelacyjnym w Warszawie.

${ }^{56}$ Ibidem.

${ }^{57}$ H. Mielnik, Sądownictwo polskie (nieniemieckie)..., s. 328.

58 W. Makowski, Kodeks karny 1932. Komentarz I. Część ogólna, Warszawa 1932, s. 181-184. Podobnie J. Makarewicz, Kodeks karny z komentarzem, Lwów 1935, s. 173. 
Zawodowym przestępcą jest w myśl przepisów kodeksu karnego ten, kto z dokonywania przestępstw uczynił sobie zawód i postanowił czerpać z tego źródła stałe środki na utrzymanie, w szczególności jest nim ten, kto przypisane mu przestępstwo popełnił pod wpływem zamiaru rozpoczęcia serii przestępstw, z których miał stworzyć sobie główne lub przynajmniej poboczne źródło dochodu ${ }^{59}$.

Być może jej wydanie nie miało żadnego związku z kryterium podziału właściwości rzeczowej w GG. W uzasadnieniu wyroku doszło do zdefiniowania pojęcia ustawowego, dlatego na jego gruncie wydano tezę prawną, rozesłaną potem do wszystkich sądów apelacyjnych i sądów w apelacji krakowskiej. Tak jak miało to miejsce w innych przypadkach.

\section{PODSUMOWANIE}

Instytucja tez prawnych sądów apelacyjnych w GG miała zastąpić działalność zlikwidowanego Sądu Najwyższego w obszarze ujednolicania orzecznictwa sądowego. Tezy prawne z zakresu prawa karnego nie były wykorzystywane politycznie. Żadnej z odnalezionych, w wyniku przeprowadzonych badań archiwalnych, tez prawnych nie można przypisać interpretacji prawa w duchu nazistowskim. Były to wypowiedzi jurydyczne sądów ostatniej instancji w GG. Miały służyć ujednolicaniu orzecznictwa sądów polskich (nieniemieckich) w GG. Biorąc pod uwagę trudne warunki codziennego funkcjonowania sądów polskich (nieniemieckich), brak dostępu do materiałów prawniczych, przedwojennych orzeczeń i opracowań, tezy prawne rozsyłane drogą służbową spełniały funkcję poznawczą i ujednolicającą. Odbywało się to głównie na podstawie autorytetu sądów apelacyjnych, podobnie jak przed wojną na podstawie orzeczenia Sądu Najwyższego. Tezy prawne nie miały bowiem charakteru wiążącego, a jedynie informacyjny i opiniodawczy.

Władze niemieckie nie zamierzały narzucać polskim (nieniemieckim) sądom określonych linii orzeczniczych poprzez tezy prawne sądów apelacyjnych. Ta instytucja prawna nie miała służyć polityzacji orzecznictwa sądowego. Władze niemieckie mogły wprowadzić inne środki, które spełniałyby takie cele, znane chociażby z polskich obszarów wcielonych do Rzeszy. Nie zdecydowano się jednak na tego typu rozwiązanie. Wynikało to przede wszystkim z przyjętego w GG systemu sądownictwa. Sądownictwo niemieckie mogło bowiem przejąć, za pośrednictwem

${ }^{59}$ ANK, Sąd Apelacyjny w Krakowie 1919-1950, sygn. 31, brak paginacji, Teza I KA 357/41. Sąd Apelacyjny w powyższym orzeczeniu położył wyraźny akcent na stronę podmiotową ,zawodowości”. Podobnie m.in. wyrok SN z 16 marca 1948 r. (K 2503/47), Zbiór Orzeczeń Sądu Najwyższego 1948/III, poz. 71. Odmienny pogląd prezentował W. Makowski. Więcej na ten temat: R. Kokot, Kilka uwag w kwestii normatywnego wyrazu przestępczości zawodowej w polskim prawie karnym, „Palestra” 2020, nr 4, s. 64-81. 
prokuratury (władzy oskarżenia) niemieckiej, każdą sprawę karną. I to sądownictwo niemieckie realizowało cele polityki nazistowskiej w GG. Nieprawomyślne dla władz niemieckich orzeczenia mogły być dodatkowo zmieniane w ramach instytucji prawa sprawdzenia, służącej do sprawowania nadzoru judykacyjnego nad orzecznictwem sądów polskich (nieniemieckich) ${ }^{60}$. Prawomocne orzeczenia mogły być na wniosek kierowników dystryktowych wydziałów sprawiedliwości sprawdzane i zmieniane przez wyższe sądy niemieckie. Ewentualne narzucanie interpretacji prawnych odbywało się poprzez wydawane okólniki, przesyłane do sądów polskich (nieniemieckich) przez dystryktowe wydziały sprawiedliwości oraz Główny Wydział Sprawiedliwości w Rządzie Generalnego Gubernatorstwa, przy czym dotyczyły one głównie prawa wydanego w $\mathrm{GG}^{61}$.

$\mathrm{Na}$ koniec należy ocenić tezy prawne z zakresu prawa karnego pod kątem postulowanego przez sędziego Kazimierza Rudnickiego „zachowania myśli prawniczej”. W zdecydowanej większości tezy prawne były oparte na przedwojennym polskim prawie karnym, które zostało utrzymane w mocy na obszarze Generalnego Gubernatorstwa. Tezy prawne polskich (nieniemieckich) sądów apelacyjnych w swojej treści nawiązywały do orzecznictwa i doktryny II Rzeczypospolitej. Dla ustroju sądownictwa polskiego (nieniemieckiego) w GG były substytutem działalności orzeczniczej Sądu Najwyższego i dążyły do wpływu na orzecznictwo. Nie stanowią one jednak w przypadku prawa karnego, jak można byłoby się spodziewać, twórczego rozwinięcia myśli prawniczej o nadzwyczajne przypadki związane z warunkami okupacji.

\section{LEGAL THESES IN THE FIELD OF PENAL LAW ISSUED BY POLISH (NON-GERMAN) COURTS OF APPEAL IN THE GENERAL GOVERNMENT (1940-1943)}

Abstract

The purpose of the article is to analyze the legal theses issued by courts of appeal in the field of penal law. The legal theses were the most important juridical statements of Polish (non-German) courts in the General Government. Detailed statistics concerning the issue

${ }^{60}$ Więcej na ten temat: H. Mielnik, Prawo sprawdzenia prawomocnych orzeczeń sądów polskich (nieniemieckich) w Generalnym Gubernatorstwie w okresie II wojny światowej. Orzecznictwo Wyższego Sądu Niemieckiego w Radomiu, „Czasopismo Prawno-Historyczne” 2020, t. 72, z. 1, s. $211-240$.

${ }^{61}$ Jako przykład można podać kwestie związane ze stosowaniem $§ 3$ rozporządzenia o sądownictwie polskim z 19 lutego 1940 r., zgodnie z którym wykluczono możliwość stosowania przez sądy „warunkowego zawieszenia kar wolnościowych lub grzywien lub udzielać innych ułaskawień". Niejasny przepis rozporządzenia został zinterpretowany w czerwcu 1940 r. przez Wydział Sprawiedliwości w Urzędzie Generalnego Gubernatora. H. Mielnik, Sądownictwo polskie (nieniemieckie)..., s. 156-157. 
under discussion are presented in the article. As a result, knowledge of the application of penal law by Polish (non-German) courts in the General Government is broadened, mainly in relation to the types of criminal cases that were heard by these courts and to the legal problems connected with them. In a broader context, this analysis will make it possible to answer the question concerning the role and activity of the Polish (non-German) courts in the General Government. Moreover, it will provide an answer whether these courts were used to implement Nazi policy in the General Government in criminal cases.

Keyw ords: General Government, Nazi law, Nazi judiciary, Second World War, Polish (non-German) judiciary, penal law 